Article

\title{
Energy System Models as a Means of Visualising Barriers and Drivers of Forest-Based Biofuels: An Interview Study of Developers and Potential Users
}

\author{
Magdalena Fallde ${ }^{1}$, Johan Torén ${ }^{2}$ and Elisabeth Wetterlund ${ }^{3, *}$ \\ 1 Department of Thematic Studies, Technology and Social Change, Linköping University, \\ SE-581 83 Linköping, Sweden; magdalena.fallde@liu.se \\ 2 RISE Research Institutes of Sweden, Eklandagatan 86, SE-412 61 Gothenburg, Sweden; johan.toren@ri.se \\ 3 Energy Engineering, Division of Energy Science, Luleå University of Technology, SE-971 87 Luleå, Sweden \\ * Correspondence: elisabeth.wetterlund@ltu.se; Tel.: +46-920-491056
}

Received: 30 August 2017; Accepted: 30 September 2017; Published: 3 October 2017

\begin{abstract}
Forest-derived biofuels have been on the agenda for several decades. Despite extensive research and development efforts, forest biofuel concepts have nevertheless not yet been realized on any significant scale. The discrepancy between the expectations from the research community and the lack of momentum regarding biofuel production raises the question of if and how research results can be used to achieve such goals. Here, we report results from an interview study with the aim of evaluating how energy system models can be used to illustrate barriers and drivers for forest biofuels, with focus on Swedish conditions, using the BeWhere model as case. The study is framed as an example of expertise, and problematizes how energy system models are interpreted among expected users. While the interviews revealed some general scepticism regarding models, and what kinds of questions they can answer, the belief was also expressed that increased complexity might be an advantage in terms of being able to accommodate more barriers against forest biofuels. The study illustrates the complexity of this policy area, where an energy system model can answer some, but never all, 'what if ... ?' questions. The results reveal a need for reformation in energy system modelling in order to more explicitly make society the subject of the work, and also illustrate that the belief in expertise as a tool for consensus-building in decision-making should be questioned.
\end{abstract}

Keywords: energy systems analysis; energy system models; biofuels; interviews; barriers and drivers; expertise

\section{Introduction}

Sweden has set an ambitious policy agenda regarding greenhouse gas emission reductions and defossilisation of the transport sector, with the long-term priority of a fossil fuel independent vehicle fleet by 2030, and a proposed target of $70-80 \%$ emission reduction from the domestic transport sector by 2030, compared to emission levels in 2010 [1-3]. In order to reach the goals, significant efforts within three main areas of action will be necessary; a transport-efficient society (including, for example, sustainable city planning, infrastructural measures and modal changes), increased vehicle energy efficiency, and renewable fuels (biofuels and electricity). In order to reach the proposed emission reduction target for 2030, 15-20 TWh biofuels would be needed, assuming a significant concurrent decrease in total transport energy demand, and continued electrification of the road transport sector [2-4].

Recent years have seen a rapid growth in the share of biofuels in the Swedish road transport fuel mix, from 5.7\% in 2010, to almost 19\% in 2016 [5], which makes Sweden the leaders in terms of biofuel use in the EU. In absolute terms, this already amounts to 17 TWh today. In contrast, other key areas of 
action are lagging, and the total energy demand for domestic transport has, after a few years of slight decline, increased again, and is currently at the highest level since 2008 (95 TWh in 2016, of which $89 \mathrm{TWh}$ in road transport) [5]. This means that unless drastic measures are taken to reduce the total energy demand for transports, the amounts of biofuels needed to reach the emission targets would need to be significantly higher than 20 TWh by 2030 .

While the majority of the biofuels used today are imported, Sweden also has an established domestic biofuel production industry with a total annual production of around 5 TWh (ethanol, biodiesel/FAME, tall oil-based HVO and biogas). In addition to this, Sweden also has an extensive history of research and development of biofuel production technologies using lignocelluosic (woody) or waste biomass feedstocks, and the total production potential has been estimated to at least 20-30 TWh biofuel from woody biomass [2,3] and 2-8 TWh biogas from anaerobic digestion [6], in addition to the current production levels.

A large number of studies have proposed integration of biofuel production with forest industries as beneficial from economic and energy efficiency perspectives for forest rich regions, see, for example, [7-14]. From a Swedish perspective, several reasons can be identified in favour of the integration of biofuel production with the forestry and forest industry sector. The forest industry is particularly well suited regarding both feedstock integration (utilisation of existing material streams, e.g., black liquor, wood chips, bark etc.) and energy integration (e.g., heat integration). In addition, integration or co-utilisation of equipment and logistics systems can contribute to reduced capital and operational costs. Further potential benefits include experience and knowhow, financial resources and strong relational networks $[15,16]$. The forest sector is of fundamental importance to the Swedish economy, and represents $9-12 \%$ of the industrial employment, exports, turnover and added value [17]. At the same time, the Swedish forest industry is currently facing challenges regarding, for example, increasing competition and energy and feedstock prices, and declining markets (mainly printing paper). Diversification and transformation into biorefineries in order also to produce, for example, biofuels for transport (or other green chemicals) has been proposed by biofuel proponents as a way to simultaneously produce sustainable advanced biofuels in an efficient way, and increase the forest industry's competitiveness [16,18-20].

Despite the fact that biofuel production integrated with forestry and the forest industry would appear to be attractive from a Swedish perspective, so far, these types of concepts have not been realized on any significant scale, but rather have mainly been limited to technology development activities (for an overview, see e.g., [16,21]). In a recent study, Peck et al. [16] investigated the system of forest-derived transport biofuels in Sweden, with particular focus on the systems' actors as well as on systemic constraints and drivers for the emergence of a significant biofuel production industry. Peck et al. showed that a number of factors can be identified as barriers to forest-based biofuel production. In particular, various policy-related issues, such as policy instability, short-termism and low predictability, have hindered biofuel initiatives from moving forward. This has resulted in eroded confidence and trust levels among industrial biofuel actors, which in turn results in even higher investment hurdles. Peck et al. also concluded that the forest sector stands divided regarding the view on forest-based biofuels, which likely undermines the efforts of biofuel proponents to secure the necessary support. Hellsmark et al. [21] also identified the lack of appropriate policies as a key barrier or system weakness. Other barriers were found in the form of lack of coordination among, for example, government ministries, agencies and regional actors, and weak industrial participation. Hellsmark et al. concluded, among other things, that knowledge about, for example, the current biorefinery development status, should be increased among policy makers, and that policy initiatives aimed at the industry are critical. Additional barriers can be identified within the forest industries themselves, such as conservative organisational culture and lack of financing, as pointed out by Näyhä and Pesonen [22].

The contradiction between, on the one hand, visions within the research community concerning sustainable fuels and transformation towards a biorefinery industry and, on the other hand, the lack 
of actual momentum regarding forest-based biofuel production, raises the question of how research results can be and are used in order to achieve such goals.

The purpose of this paper is to evaluate if and how energy system models can be used to illustrate opportunities and obstacles for forest-derived biofuel production, with a focus on Swedish conditions. This study is therefore framed as an example of expertise, problematising how energy system models and the results from them can be used and are interpreted. Previous research has discerned the high expectations of expert opinions from researchers, in particular regarding sustainability [23]. This study analyses how an energy system model and its results are interpreted among its potential users (in this paper we use the term "users" to denote users/recipients of the model results, rather than the actual model users/operators, as the model under study has not been adapted for use by non-experts). Thereby, the discrepancy between actors' interpretations and the model's results concerning forest-derived biofuels will be identified. The energy system model BeWhere is used as an example case, in order to form a bridge between the theoretical framework and real-world application, with a focus on visualisation of barriers and drivers of forest-based biofuels. The choice of model to study is motivated by the fact that the BeWhere model was explicitly developed to analyse forest-based biofuel production for the intended region (Sweden), and that it is, to the best of the authors' knowledge, the only model currently in use with this specialised focus.

The following research questions will work as guidance for fulfilling this purpose:

- What barriers and drivers concerning forest-derived biofuel production in Sweden do the interviewed actors identity?

- How do these potential users interpret models in general, concerning forest-derived biofuel production? How do they interpret results from the case study model (BeWhere)?

- What discrepancies between the scope of and results from the studied model and the potential users' interpretations and expectations can be identified?

The interviewed actors represent potential users and developers of the BeWhere model, and represent different areas of expertise.

The paper is organized as follows: Chapter 2 gives a background of the BeWhere model. Chapter 3 describes the theoretical framework, where expertise and the understanding of models are discussed. Next, the methodology for data collection and, in particular, the choice of interviewees is presented. Chapter 5 presents the results of the study, and finally, Chapter 6 contains a concluding discussion.

\section{Background-The BeWhere Model}

This chapter gives a brief introduction and overview of the model used as a case in this study, the BeWhere model. For more details, see $[8,24,25]$ and the official BeWhere webpage: www.iiasa.ac. at/bewhere.

\subsection{Model Overview}

BeWhere is a model family of techno-economic, geographically explicit, bottom-up optimisation models that are used to analyse localisations and properties of different energy conversion plants. The model has been applied at local, national and supranational levels. Initially the scope of application was limited to bioenergy plants, e.g., [26-31], but this has, in recent years, been expanded to also include, for example, solar, wind, hydropower, public transport, and algae-based plants [32-35]. BeWhere is based on mixed-integer linear programming (MILP). The model is written in the commercial software GAMS using CPLEX as a solver.

BeWhere was developed with the ambition to investigate different policy instruments and to provide decision support for the development of, for example, strategies and policies [36]. One example of recent policy targeted use of BeWhere is within the S2Biom project [37], where the model was used as part of an integrated toolset aimed at developing harmonised data sets, strategies and roadmaps at geographical levels ranging from the local up to the pan-European level (more information can be 
found at the project webpage: http:/ /www.s2biom.eu/en/about-s2biom.html). Another example, at the local/regional level, involves the design and localisation of charging infrastructure for electric buses in Stockholm, Sweden, where the BeWhere model was used in collaboration with representatives for the local public transportation company, as well as concerned municipalities [35].

BeWhere Sweden (in this paper, the term "BeWhere" will also be used generally to denote the specific "BeWhere Sweden" model) is focused particularly on forest biomass, biofuel production and design of forest-based value chains. BeWhere Sweden shares the model structure and a number of assumptions with the supranational BeWhere Europe model, but with a higher degree of detail regarding the biomass supply, as well as industrially integrated biofuel production, where potential plant hosts are largely modelled individually. BeWhere Sweden is primarily used to analyse how future bio-based value chains can be implemented cost-effectively from a system perspective, what role the existing energy infrastructure (industry and energy facilities) can play, and how different parameters affect, for example, the choice of conversion technologies, localisation, and integration, in a system where the same limited resource (biomass) is also in demand from other sectors. The parameters considered include, for example, policy instruments, future scenarios for energy market conditions, technological development and industrial investment opportunities. The results are envisioned to be useful as decision support for stakeholders in, for example, biofuel production, as well as for policy makers.

The BeWhere Sweden model is geographically explicit regarding supply and use of biomass (including harvesting and collection costs for different forest assortments), potential locations for biofuels production, and transport infrastructure. The model minimises the cost of the entire studied system to simultaneously meet a certain defined biofuel production demand, as well as the demand for biomass from other sectors. The system cost includes costs and revenues for production and transportation of biomass, production facilities, transportation and delivery of biofuels, by-products sales, and economic policy instruments. The cost is minimised under a number of constraints that describe and limit, for example, supply and demand for biomass, possible import and export of biomass, plant operation and demand for end products. The model will thus choose the least costly combinations of feedstocks, production facilities and biofuel distribution, while simultaneously meeting the demand for biomass in other sectors. The model is relatively flexible, and can be adapted to, for example, analyse different scenarios.

The resulting model output includes a set of new biofuel production facilities in order to meet the defined production target, the resulting supply chain configurations, the origin of used biomass, and costs related to the different parts of the supply chain. Figure 1 gives an overview of the BeWhere Sweden model. For more details, see $[8,24,25]$.

As it is a cost minimisation model, the scope for analysing drivers and barriers is mainly focused on economic aspects, such as costs in different parts of the production chain, costs and revenues related to policies, and economic risks. The geographically explicit component also makes it possible to analyse, for example, drivers related to co-location benefits or industrial cluster synergies, as well as barriers related to local or regional feedstock competition and logistical obstacles. 


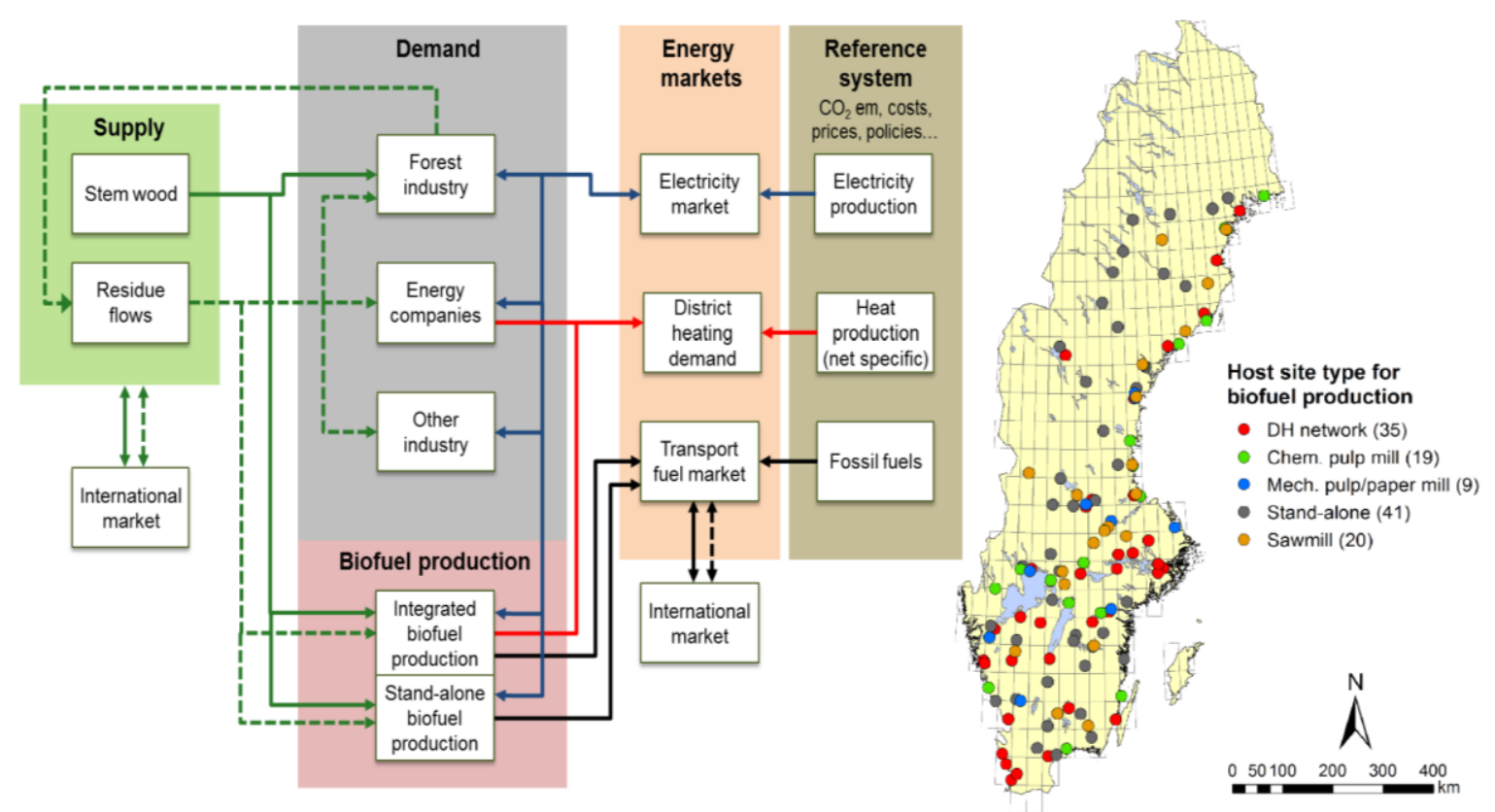

Figure 1. Schematic overview of the main flows in the BeWhere Sweden model (left) and geographical representation (right). Biomass supply and demand, district heating systems, transport fuel demand, and potential new locations for biofuel production (host sites) are represented geographically explicitly, while the electricity market and energy market scenarios are represented at the national level.

\subsection{The BeWhere Project(s)}

In 2006, the development of the BeWhere model started at the International Institute for Applied Systems Analysis (IIASA) in Austria and Luleå University of Technology (LTU) in Sweden. The model is under constant development and is being operated today for different geographical regions by IIASA developers, as well as by external developers and model operators. The current BeWhere Sweden model, which is the focus of this study, has been developed and operated at LTU since 2012.

The development of the BeWhere Sweden model has been made within a series of externally funded research projects. A number of researchers from different institutions with complementary competences and backgrounds have participated in these projects. In addition to this, several of the research projects have had external reference groups connected with them, in order to get input from outside the research group. The reference groups have consisted of a mix of representatives from industry, energy companies, academia and governmental agencies.

\section{Theoretical Concepts of Models and the Validation of Models}

The theoretical framing of this paper involves potential users' perspectives of models. A specific energy system model is studied in order to analyse how it can be used and how it is interpreted as a means of visualising opportunities, drivers and barriers for forest-derived biofuel production. The scope and output of the energy system model is compared to the actual barriers and drivers as seen by the potential users of the model and model results.

In this context, the energy system model-and models in general-illustrates what can be defined as expertise. According to Fischer [38] (p. 2), we live in "the age of expertise", meaning that 'experts' have a central position in today's society, where policy makers, as well as citizens, are dependent on the verdicts from experts. In particular, as will be further discussed below, politicians are dependent on experts and the validity of their reports, which have often been interpreted as independent and unbiased.

However, the independence of research has been questioned and criticised. According to Jasanoff [39], knowledge production and expertise is constantly influenced by society, but society is 
also influenced by the expertise. As Jasanoff [39] (p. 3) puts it, science and society must be understood as co-produced:

"Scientific knowledge, in particular, is not a transcendent mirror of reality. It both embeds and is embedded in social practices, identities, norms, conventions, discourses, instruments and institutions"

Therefore, knowledge production can never be understood as a neutral output, and the expertise represented, for example, in energy system models must always be interpreted in the societal context in which the models have been developed.

This study focuses on models and models as an expression of expertise. As Oreskes [40] describes, the term "model" can today primarily be understood as a computerized model of a parameterized complex system, often involving simulations. In particular, the purpose of a model is to be able to ask the question "what if ...?", and by integrating different data, be able to contribute to an understanding of that answer, and thus provide a forecast of the future [40,41]. However, it is essential to bear in mind that the input to the model, which is then analysed, influences the output, and thereby the 'forecasting of the future'. At the same time, this input, which might consist of a mix of different components, together influences and shapes the output/results. This means that the components are fixed, which makes the model focus on a closed system. According to Oreskes [41] (p. 1455) "real-life systems are never closed", meaning that the reality that they are trying to analyse always involves influences from components not included in the input determined by the model developers.

Energy system models are typically constructed as tools to predict, explain or control the behaviour of complex real-world energy systems. One area of use often emphasised is as a tool to support decision makers in, for example, policy making [42]. As such, energy system models can be used to highlight the existence of barriers for the implementation of polices. An identified gap between the output of the energy system model and the real-world situation can then serve as a starting point for further analysis of the barriers [43]. As with all models, energy system models by necessity represent a compromise between reality and manageability. As a model is designed as an approximation of reality, it must be manageable in the sense that it can yield understanding and knowledge that cannot be obtained by direct observation of the complex real-world system. The literature on different types, categories and classifications of energy system models is plentiful, but falls outside the scope of this paper (see e.g., [43-46]).

In order to create a model that can be validated and actually involves components that together help illustrate the real world, it would be positive to broaden the input parameters. However, Oreskes [40] problematises this effort and refers to what she defines as "the complexity paradox". That is, the effort to create a model that is close to reality actually risks making it more unsecure. In order to be more realistic, and thus to result in an output that takes a multitude of different components into consideration, the input must in turn consist of many different parameters. At the same time, all variables that go into the model involve a certain amount of uncertainty. The more complex the model is with all these variables, the more unsecure it becomes. "The 'truer' the model, the more difficult it is to show that it is 'true'" Oreskes [40] (p. 20) explains. The complexity paradox thus means that every new variable that is added into the model also makes it more unsecure.

Knowledge production is sometimes expected to work as a linear process where experts give a neutral and 'true' description of reality, which can be used by decision-makers in order to solve concrete problems. Decision-making, in line with this linear process, is thereby based on new, neutral information from experts. Science and expertise thus help to create political consensus [47]. Of course, the expected linearity within research, as well as in policy, has been questioned. The notion of expertise and knowledge production as neutral has been problematised, as described above, but the interrelationship between them has raised further questions. On the one hand, decision-makers, according to Fischer [38] (p. 4), "are left to depend on and trust the validity of the knowledge and competences of the experts who made them". On the other hand, studies also show that researchers 
and experts are indeed dependent on policy makers [48]. Lidskog and Sundqvist [23] suggest that policy constantly influences knowledge production, but knowledge and science support and help legitimise policy. According to Haas [48] (p. 575) research results that can be used by policy makers must "represent consensus, and be provided through a medium that is politically palatable".

To summarise, questions like what results models might show, and how they are actually used in practice, are constantly problematised. As described in Chapter 2, the energy system model that is studied in this paper is currently used mainly within the context of research, but with the ambition to influence policy makers.

\section{Methodology and Data Collection}

Data collection was mainly based on semi-structured interviews [49], with the goal of capturing the interviewees' reflections and interpretations in relation to three themes:

1. Barriers to and drivers for forest-based biofuel production

2. The use of models in order to visualise and analyse such drivers and barriers

3. The case study model BeWhere as a means of illustrating barriers to and drivers for forest-based biofuel production

In Figure 2, the scope of the analysis is visualised graphically. The figure illustrates the relationships (red arrows) between the complex real-world system (upper part of figure) and the simplified model approximation of the system (lower part of figure). Focus is on drivers for and barriers to fuel production from forest biomass, how this can be captured by energy system models in general, and the case study model BeWhere in particular, and how this in turn is interpreted by actors in the system.
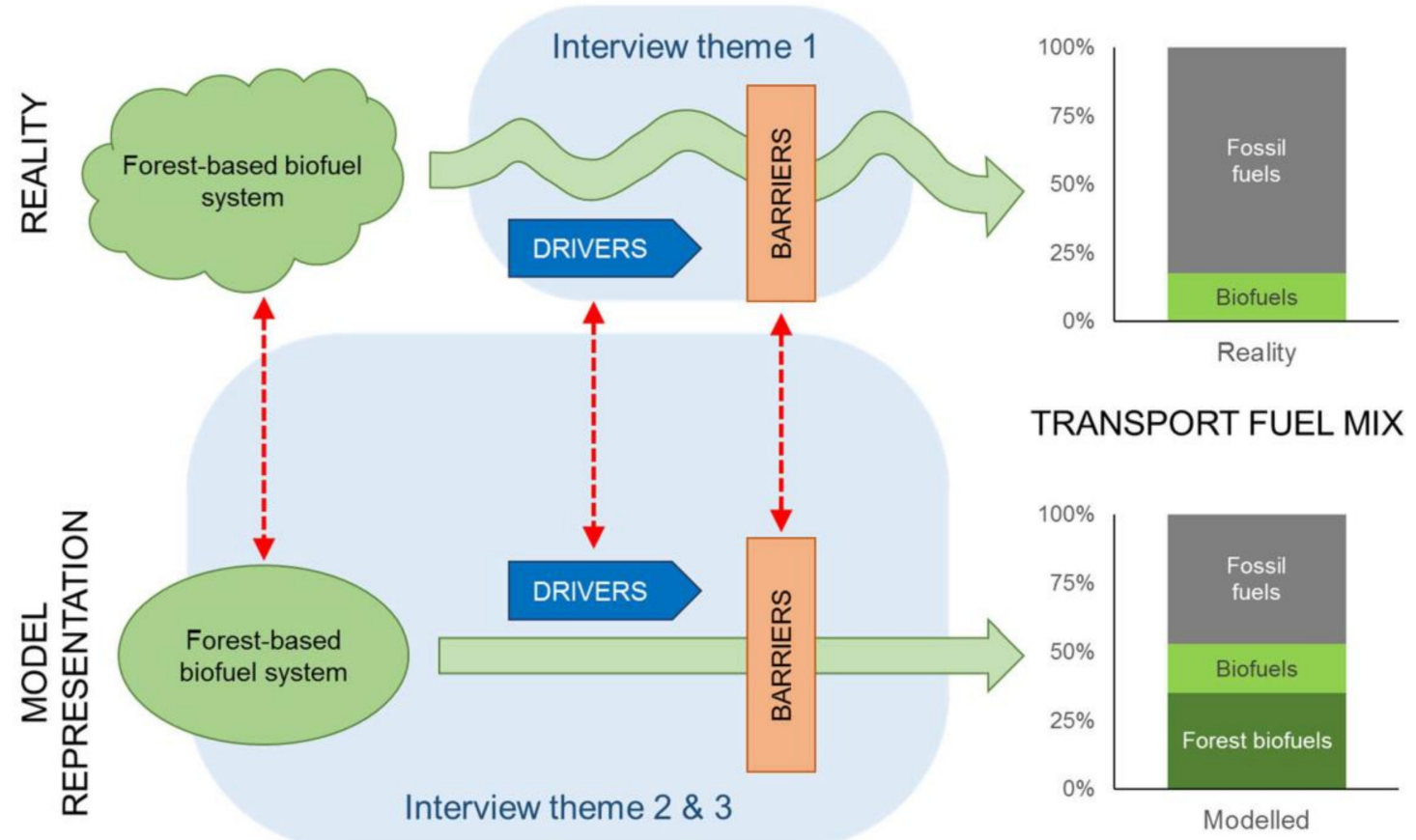

TRANSPORT FUEL MIX

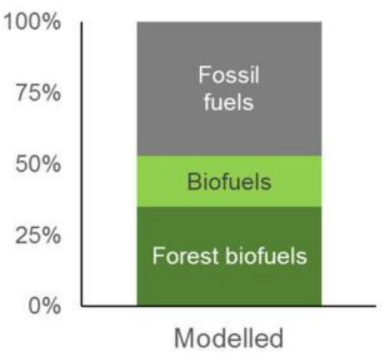

Figure 2. Graphical overview of the scope of and themes for the interviews. The upper half of the figure represents the complex real-world system under study (forest-based biofuel production), while the lower half represents the modelled approximation of the reality. Theme 1 concerns real-world barriers to and drivers for forest-based biofuel production. Theme 2 concerns the use of energy system models in general to visualise such barriers and drivers, while theme 3 concerns the case study model BeWhere as a means to illustrate barriers and drivers. 
These three themes were used as inspiration when creating the interview guides that were used during the interviews, as well as when analysing the answers. Because one of the themes focused on the interviewees' interpretations of the BeWhere model, one part of the interviews was also dedicated to presenting the model and the results from the model. This part was adapted according to the interviewees' previous knowledge and understanding of the model.

The selection of actors to be interviewed was made in order to represent the most relevant parts of both the studied core system and of the surrounding systems, as illustrated schematically in Figure 3. As such, the selection of interviewees was broadened from "the usual suspects" (i.e., actors more directly related to the biofuel production industry), whose views on barriers and drivers for forest-based biofuels have already been extensively analysed $[16,50]$. Several of the interviewees had previous knowledge or experience of the BeWhere model, to varying extents. The motivation for choosing those actors was to ensure a minimum level of model understanding (general as well as the regarding specific case model), in order to limit the need for extensive model explanations, and to thus risk losing track of the key points of the interviews.

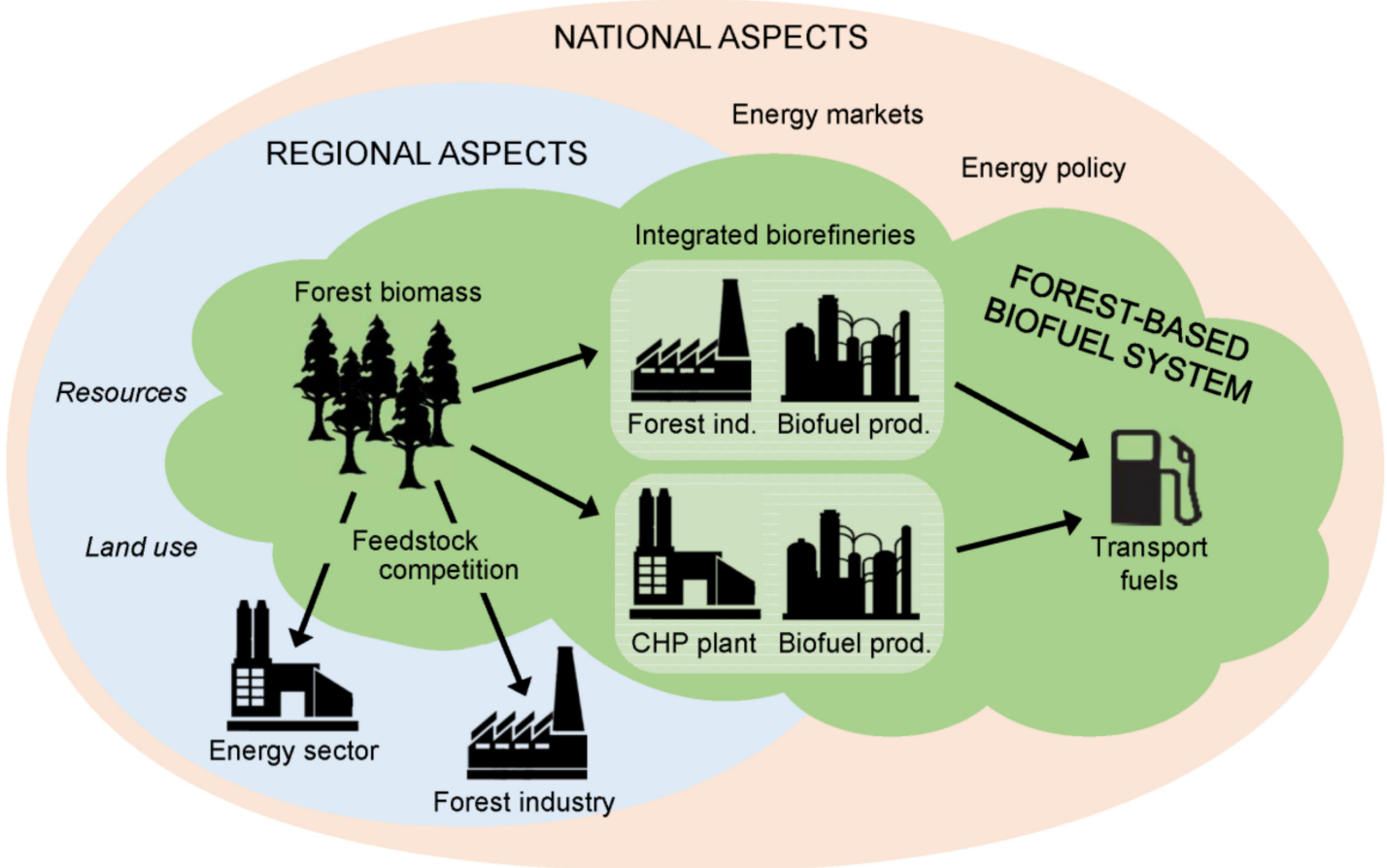

Figure 3. Overview of the forest-based biofuel system in focus in this study, including important surrounding systems (regional as well as national). Aspects in italics are not covered by the case study model BeWhere, but have been included in this study.

Two groups of actors were interviewed, with a total of eight interviewees. The first group consisted of potential users of the model results, representing several sectors: the forestry and forest industry, the energy sector, and national and regional authorities. These interviewees are referred to as U1-U6. Within this group, several interviewees have been involved in the BeWhere project as reference group participants. The second group of interviewees consisted of researchers that have been involved with the BeWhere model as developers. In addition to the themes mentioned above, these interviews also focused on the aim and the development of the specific case study model. These interviewees are referred to as D1 and D2. Table 1 gives an overview of the interviewees, as well as their respective areas of expertise and competence.

The interviews lasted for 40-80 $\mathrm{min}$, and were all recorded and transcribed. 
Table 1. List of interviewees and their respective areas of competence (varying levels within each competence area).

\begin{tabular}{|c|c|c|c|c|c|c|c|c|c|}
\hline \multirow[b]{2}{*}{ Designation } & \multirow[b]{2}{*}{$\begin{array}{c}\text { Sector/ } \\
\text { Organization }\end{array}$} & \multicolumn{7}{|c|}{ Areas of Expertise and Competence } & \multirow[b]{2}{*}{$\begin{array}{l}\text { Previous } \\
\text { BeWhere } \\
\text { Experience/ } \\
\text { Knowledge }\end{array}$} \\
\hline & & $\begin{array}{l}\text { Forestry/ } \\
\text { Forest } \\
\text { Industry }\end{array}$ & $\begin{array}{c}\text { Energy } \\
\text { Sector/ } \\
\text { Energy } \\
\text { Systems }\end{array}$ & $\begin{array}{l}\text { Biofuel } \\
\text { Prod. }\end{array}$ & $\begin{array}{c}\text { Local/ } \\
\text { Regional } \\
\text { Aspects }\end{array}$ & $\begin{array}{l}\text { National } \\
\text { Aspects }\end{array}$ & $\begin{array}{l}\text { Energy } \\
\text { Policy }\end{array}$ & $\begin{array}{l}\text { Energy } \\
\text { System } \\
\text { Models }\end{array}$ & \\
\hline U1 & $\begin{array}{l}\text { Regional } \\
\text { authority }\end{array}$ & $\mathrm{x}$ & & & $x$ & $\mathrm{x}$ & & & low \\
\hline $\mathrm{U} 2$ & $\begin{array}{l}\text { Regional } \\
\text { authority }\end{array}$ & $\mathrm{x}$ & & & $\mathrm{x}$ & & & & none \\
\hline U3 & State authority & & $\mathrm{x}$ & & & $x$ & $\mathrm{x}$ & $x$ & low * \\
\hline $\mathrm{U} 4$ & Energy sector & & $\mathrm{x}$ & $x$ & $x$ & & & & medium * \\
\hline U5 & Forest industry & $x$ & $x$ & & & & & & low \\
\hline U6 & Forest industry & $x$ & & $x$ & & & & & none \\
\hline D1 & $\begin{array}{l}\text { Research } \\
\text { institute }\end{array}$ & & $\mathrm{x}$ & $x$ & & & $\mathrm{x}$ & $\mathrm{x}$ & high \\
\hline D2 & $\begin{array}{l}\text { University/ } \\
\text { energy sector }\end{array}$ & & $\mathrm{x}$ & & $x$ & $x$ & $x$ & $x$ & high * \\
\hline
\end{tabular}

Interviewees marked with * under "Previous BeWhere experience/knowledge" are or have been involved in the BeWhere project as reference group participants.

\section{Results}

In this chapter, the results from the interviews are presented. First, interviewed actors' perspectives of drivers and barriers for forest-based biofuel production are presented in Sections 5.1 and 5.2 (interview theme 1). Second, interpretations of models in general (interview theme 2) and the BeWhere model in particular (interview theme 3) are presented in Section 5.3.

\subsection{Forest-Based Biofuel Production: Drivers ...}

In this section, interviewed actors' interpretations concerning drivers behind forest-derived biofuel production will be presented and discussed. As described in Chapter 4, the actors represent regional and national authorities as well as private actors from the forest industry and the energy sector.

Drivers for forest-based biofuel production can be divided into three categories, although of different importance for the interviewed actors. First, climate change mitigation is mentioned as a driver for engaging in biofuel production. According to U5, representing a state-owned forestry company that can also be seen as a forest industry interest organization, the forest sector might work as "a tool for climate change mitigation". In a similar vein, U1, U2 and U3, all representing different authorities, refer to the forest as a resource, possible to use for example within climate mitigation actions.

However, interviewees also emphasise a second driver: the changed market and conditions for pulp and paper mills. During recent decades, the conditions for the European pulp and paper industry have hardened. Despite a relatively stable total global demand for pulp and paper products (reduced demand for printing paper, in particular newsprint, is compensated by an increased demand for packaging paper and paperboard, as well as for soft paper), the European industry has become more exposed to changes related to global competition from lower cost regions (Latin America and Southeast Asia in particular), higher costs for feedstock and energy, and an increasing complexity of industry regulation [51]. As a result, European pulp and paper production has seemingly stagnated during the last few decades, diminishing to a level significantly lower than the peak before the financial crisis in 2007-2008, and with a steadily declining number of pulp and paper mills [52]. From a Swedish perspective, the trend follows that of the European pulp and paper industry [17]. Among the interviewed actors, representing the forest industry as well as state and regional authorities, possibilities for a new market for the forest industry are therefore interpreted as an important driver. According to U3 and U5, the reduced demand for products from paper and pulp mills has changed the attitude to new markets within these industries. U5, describes: 
"When we started to work with these issues, you could almost be lambasted by the paper and pulp mills because they thought it was really stupid. Why should we investigate biofuels? [ . . ] The concern was that it would interfere with their business and their production of pulp."

Apart from the concern that the biomass would be used for producing biofuels and that this would lead to higher pulp wood prices, U3 also interprets the forest industry as being sceptical when it comes to new markets that differ from the traditional market. U3 explains:

"It has to do with an attitude of using the forest for something that is not really their business, that is not the genuine business, what you are used to: pulp, furniture [ ... ] Using the forest to produce biofuels is probably not the original imagination you had in the forest industry. But this is changed now."

However, this scepticism changed due to the changed market for the industry. According to U5, this made the forest industry, and in particular the forestry sector, search for new markets and new products, and thereby see biofuel production as 'an extra market', as U3 put it.

Finally, a third driver can be discerned that concerns not only new markets, but rather the already established production. Here, biofuel production is interpreted as a part of the waste-management system for handling by-products from the pulp and paper mills. U1, representing a regional authority, explains that the industries can use biofuel production as a way to shift various by-product flows from a cost to a potential profit:

"... [the large forest industries] have by-products that are difficult to handle, and that's what is driving them, they are costly to deposit. Biofuel production is a good way to handle the waste or by-products."

In the same vein, biofuel production can be a way to utilise existing process equipment more efficiently. Lignin separation and black liquor gasification have been proposed as ways to reduce the load on (or "debottleneck") the recovery boiler in kraft pulp mills (see e.g., [53-55]), thus enabling increased pulp production. According to U6, representing a forest industry, separation of lignin from black liquor today only generates costs and no extra revenues, aside from the increased pulp production. Hence, the possibility of extra revenue and of utilising hidden potential creates a possible driver.

\section{2. ... and Barriers}

Even though new markets are regarded as a possibility among the interviewed actors, they are complemented or shaded by different barriers. Firstly, technical barriers are discussed in Section 5.2.1, and various financial barriers summarised in Section 5.2.2. Finally, interest contradiction concerning forest and land use as a barrier is analysed in Section 5.2.3.

\subsubsection{Technical Barriers}

Technical aspects are discussed among the interviewees, related to the fact that mature technologies for large-scale forest-based biofuel production are largely missing today [56]. The exception is HVO, which can be produced from crude tall oil (a by-product of pulp making). Tall-oil based HVO has reached technological maturity and is produced on an industrial scale in Sweden and Finland. The potential for increased production is, however, limited [4]. While technologies for production of lignocellulosic ethanol from agricultural residues are on the verge of becoming commercial, technologies aiming at producing ethanol from forest-based feedstocks have not yet reached industrial demonstration scale. Similarly, gasification technologies are also lagging, although a number of small-scale and pilot plants are or have been in operation. To summarize, uncertainties related to technology readiness levels and the barriers this entails are discussed among most of the interviewees. 


\subsubsection{Financial Barriers}

The barriers that the interviewees mainly focus on revolve around what can be summarised as financial barriers. In a multi-case study focusing on Swedish forestry, Peck et al. [16] concluded that the studied industries' perception of risk has increased during the last decade. These risks are, to a high degree, connected to policies and, for example, stability and predictability with regard to supporting regulations. Such policy risks have also been discussed among the interviewees in this study, where, for example, tax alleviations are mentioned. Additionally, risks are connected to investments and the expected costs for producing biofuels. For example, U6 states, "it is a general trend. You just don't dare to take risks". Of course, this can also be added to the risks described regarding policy instruments.

According to U3, who represents a national authority, competition between biofuels is significant, which in turn increases the perceived risks of investing in a certain production. During the interviews, the comparison was also made with the situation for high-blended ethanol (E85) in Sweden (interview U3; U4). U4, who represents an energy company, says:

"One barrier is that there is an unwillingness to decide anything that later turns out to be wrong, as was for example the case with ethanol in Sweden. You don't want to do that again. There has been a reluctance to determine a winner of technology [ ... ] Then there is a risk that there will be nothing at all."

Ethanol use saw a rapid increase in Sweden during 2005-2008 [57]. However, since 2012, the use of high-blended ethanol has plummeted to around a quarter of the peak volume [5]. Kastensson and Börjesson [57] analysed the rise and fall of the E85 market in Sweden and concluded that, even though pricing of ethanol compared to fossil gasoline plays a role, it cannot fully explain the deflation of the market. Instead, policies and policy instruments were found to be crucial factors-both in the rapid expansion of the market and, when incentives were removed, in the market decline. Further, the lack of political perseverance contributed to a loss of legitimacy, economic losses for investors, reduced willingness to invest in renewable fuels, and an increase in the perceived risks in investing in such systems.

Clearly, the results show that, even though the interviewees find the Swedish forest industry suitable for hosting new biofuel production, they have great concerns regarding the technical, political and financial barriers of such productions. Next, the barrier defined as interest contradictions connected to forests and land use will be analysed.

\subsubsection{Forests and Land Use as Interest Contradictions}

Issues regarding investment costs, technology and policy instruments that interviewees consider to be barriers for forest-derived biofuel production have all been identified as key barriers against forest-based biofuel production, in this study as well as in previous work $[16,21,22,50]$. Another barrier, which has been described as essential by interviewees representing local/regional and state authorities, concerns the question of how to use the forest and conflicts regarding land use. Here, it is important to note that this barrier is only emphasised among the authorities, and has not been problematised by the interviewees representing developers of the model or representatives from the energy or forest industry. One of these interviewees, U1, representing a regional authority in a Swedish region, summarises this barrier:

"My first reflection is that this is a huge conflict area. There are very, very intense interest contradictions in this issue."

Approaching these 'interests' means that focus is turned from questions that presume that biomass residues from forests should be used for production of biofuels or other commodities or energy carriers, to instead problematising forests as resources. Here, the conflicts involve several different aspects, where issues regarding environmental values other than climate change mitigation, in particular the 
issue of biodiversity, are in the centre. Lindahl et al. [58] describe the processes and policy objectives that influence the forest policy in Sweden. According to the authors, forest policy is influenced by a multitude of different objectives, whereby different interests, although sometimes contradictory, are included. These kinds of contradictory interests regarding forests are also acknowledged in this study by interviewees representing regional and state authorities. For example, U3 states that:

"This question also concerns considerations of biodiversity, for example. It is good to have domestic resources but there are also animals that can be affected by production. There are disadvantages even though the source is renewable."

Policy objectives for forests have previously had great visions concerning the possibilities of using the biomass for biofuel production. In the governmental bill A Forest Policy in Line with the Times [59], the connection between forest policy objectives and climate mitigation objectives is discussed. It is concluded that forest-derived resources can and should be used in order to fulfil climate-oriented policy objectives. Further, the governmental investigation Possibilities for Intensive Forestry [60] describes how forest-derived biomass might have an important role as a substitute for fossil fuels, and thereby contribute to climate mitigation. As a result, the demand for forest-derived energy production was expected to increase, which meant that forests could be used outside of their traditional areas of use.

In the governmental bill A Swedish Strategy for Biodiversity and Ecosystem Services [61], ecological sustainability, in particular values from ecosystem services, was emphasised. The tension between biodiversity and production-oriented perspectives of forest-derived bioenergy has therefore been discussed amongst interviewees (interview, U1; U2; U3). Interviewees U1 and U2 both represent the regional authority of Norrbotten, in a geographic area where 50 percent of the land area is covered with forests, and where eight national parks (i.e., 95 per cent of the total national park area in Sweden) can also be found. In addition, the area of Laponia in the region is classified as a world heritage site, and several villages of the indigenous Sami people are located there [62]. According to U1 and U2, the geographical areas that they are connected to in their daily work involve all these different interests: the forest as industrial raw material, the possibility to use it for example for biofuel production, the forest as tourism, the forest as home for the Sami, etc. U1 says:

"This conflict has always been here, but it's more critical now. To a certain point it is a question of climate mitigation and how to change the world. We do not agree on how, and that starts to be more evident now."

To conclude, interviewees representing regional and national authorities consider that one important barrier to forest-derived biofuel production lies in the interest contradictions connected to land use. Before moving on to the analysis regarding themes 2 and 3, which both concern interpretations of models and model results, it can be noted that this creates a key difference in how different potential users, as well as developers, of the case study model look upon barriers regarding forest-derived biofuel production.

\subsection{Energy System Models as Tools for Evaluating Drivers and Barriers}

This section will discuss how interviewed developers as well as potential users value energy system models in general and, in particular, the BeWhere model. Whereas the previous sections focused on the expected drivers and barriers for forest-derived biofuel production in Sweden in general, this section contributes the perspective of models and how models-according to the interviewees-can be used to capture these drivers and barriers. In Sections 5.3.1 and 5.3.2, the following questions will be discussed: How is the case study model BeWhere and its results interpreted among the interviewees? How do the interviewees, in general, interpret and value results from (energy system) models? 


\subsubsection{The BeWhere Model and Interpretations of Its Results}

Section 2.1 gave an overview of the BeWhere model. When asked what aspects of the models could be used and why, several interviewees (interview, D1; D2; U3) mention the geographically explicit function. According to the interviewed developers, D1 and D2, this function was one of the reasons why the model was developed: in order to shape a tool to plan localisations of, for example, biofuel production; and also to complement other energy system models. Further, the geographical function also serves as a tool for calculating the total production costs of the produced biofuels. In order to evaluate such costs, the geographical function can be used to calculate expected transportation costs, depending on where production plants would be located (interview, D1; D2; U3). One expectation regarding this function also lies in the progress of the model, and the assumed goal of producing a model close to reality. According to D1, the model is updated for every 'new' scope or area that is studied. Here, specific components might be included and evaluated in the model. For example, ecosystem services were included as a parameter when the Alps region was modelled using the BeWhere model.

When describing the model and the reasons for using it, it is also important to problematise who the intended users of the model and the model results are. The interviewees consist of civil servants from regional and national authorities, but also actors representing or with connections to the forest industry. In addition, the developers of the model that have used it for research were interviewed. According to the developers D1 and D2, the intention is that the model will progress from being used only for research, to also being used as a tool for policy makers, or, as D1 states:

"As guideline for policy makers in order to provide information of policies to implement in their regions or country to produce specific biofuels. It is mainly a tool to help policy makers."

Thus, among the interviewees, it is clear that potential users of results from the model mainly consist of civil servants investigating biofuel production in a national, but also in a regional context (interview, D1; D2; U1-6). In addition, the interviewees representing the forest industry also see themselves as potential users of the results presented from the model (interview, U5; U6).

\subsubsection{Reflections on Models and How They Could (and Should?) Be Used}

In this section, interviewees' general reflections on models will be problematised. A general view among the interviewees is that models and the results from models can and should be used in investigations and as a basis for decision-making. According to U3, representing a national authority, models and their results are often used within the authority in order to prepare decision-making, but also as scenarios in investigations with the same intention. According to U1 and U2, models can be used in order to legitimise a standpoint in situations where conflicts of interest appear. However, using models is also associated with a complexity, mainly concerning what has been referred to as "the black box". According to the developers of the model, models are often seen as black boxes, giving results that might be (too) complex to understand without analysing the data that goes into the model. One of the developers, D2, states:

"You have to be modest and understand that it is a tool whose results depend on the input."

This is also recognized by U4 regarding the studied BeWhere model, i.e., that this kind of energy system model might be very sensitive concerning the input. Thereby, the results can also change considerably when changing the input. Further, U4 states that:

"The presentation [of the results] must be complemented with an interpretation."

Hence, according to U4, the results from energy system models must always be explained further. This is also emphasized among the representatives from state and regional authorities. In order to use the results from models as a basis for decision-making, it is essential to understand the assumptions 
that have been integrated in the model, and which have thereby influenced the results (interview, U1; U2; U3). A further consequence of this is, according to U1 and U2, that it is important to critically investigate who has developed the model and why, before even starting to analyse the results from it. Here, models developed in academia or models used within governmental authorities should also be critically evaluated before being exercised in a public authority, such as the authority that U1 and U2 represent. In addition, U3 exemplifies the opposite perspective, where results from models have been used outside of their contexts. For example, when parts of the results from a model that analyse energy markets are used in order to predict employment market policies, when the model is not developed to analyse such components.

Even though the developers of the model used as case study here, and the potential users state that this model, as well as other models, could be used for decision-making and for governmental investigations, for example, they are nevertheless very concerned regarding models in general and how they are used. Mainly, this concerns the use of models where the results are interpreted as 'facts' or truth. U3 exemplifies this:

"Sometimes results are presented as precise facts. [ ... I If you write 44.9, why not write 45? Now and again you hear that decimals should not be used because it's ridiculous in a 30-year perspective. Of course, you can receive an answer that is mathematically exact. But that doesn't have anything to do with the future."

This is also problematised by U4, stating that a model can never be understood without the input from researchers working with it. "The model can never become better than its input, the assumptions made", according to U4. This means that a model and the results from the model must be understood as a synthesis from the different assumptions made by the developers of the model. The different assumptions that become the model input could be a strength for the model because it considers many different perspectives when the results are calculated. Conversely, erroneous assumptions might harm the results considerably. That is, the more assumptions that are included in a model, the higher the probability of a flawed output from the model.

Finally, reflections from interviewees also contain the perspectives that models can never include. For example, U3 mentions how anthropological studies have found that house owners investing in solar cells were influenced by their neighbours as much as by policy instruments from governmental authorities. That is, social factors cannot be modelled, but might have a great influence on the context that the model is trying to analyse. Similarly, that many actors' perception of risks (e.g., political, technological and economic risks) has increased over time is not captured by the model studied here, but may have a large influence on the willingness to invest. This timing aspect is, for example, mentioned by both U4 and D2, and confirms findings by Peck et al. [16] and Kastensson and Börjesson [57].

\section{Concluding Discussion}

One purpose of this study has been to investigate if and how energy system models can help in analysing obstacles and opportunities for forest-derived biofuel production. The existing energy system model BeWhere has been used as a case study in order to build a bridge between the theoretical framework and examples of real-world application. Hence, potential users and developers of the BeWhere model have been targeted in the interviews in order to investigate what barriers and drivers they perceive, and to compare this with what is actually captured by the model itself. In this section, we will discuss the discrepancies we have identified between potential users' interpretations and the scope of the studied model. In the discussion, the theoretical concepts from Section 3 will be used in order to problematise the results from the interviews as a matter of expertise.

Earlier studies (e.g., $[16,21,22,50]$ ) have indicated several obstacles regarding forest-derived biofuel production in Sweden. First and foremost, policy-related aspects (or more specifically, lack of predictably stable policy conditions) have created difficult conditions for large-scale deployment of 
this kind of biofuel production, which in turn has led to a perceived higher risk now, compared to a few years ago. In addition to this, lack of coordination among different actors, weak industrial participation, conservative organisational industrial culture, low fossil fuel prices and lack of financing constitute obstacles.

In general, energy system models are good for identifying and analysing various economic barriers for the introduction of, for example, renewable energy technologies. In contrast, they usually over-simplify or omit the relationships between the energy system being studied and other issues, as was concluded in an extensive energy model review by Nakata et al. [43]. In this regard, the studied BeWhere model is no exception. It has thus mainly been focused on and developed to analyse opportunities and barriers related to geographical localisation, and strategies for reducing supply chain costs in order to minimise the cost gap to fossil fuels, as well as to investigate necessary policy support in order to make investments feasible.

According to Oreskes [40], a model can be used in order to ask 'what if ... ?' questions. In this respect, the interviewed potential users of the model studied here find the BeWhere model useable as part of the investigation needed for decision-making—e.g., as an exemplifying scenario. Even though the model could help to illustrate different scenarios and support decision-making, the obstacles that potential users foresee concerning forest-derived biofuel production are, nevertheless, mainly found outside of the components that influence the results of the model. Instead, the barriers that potential users find most critical focus mainly on social and, to a certain extent, on political factors that are not acknowledged in the model. Whereas interviewees representing the forest industry see unpredictable policy instruments as an obstacle that influences future action (compare Peck et al. [16]), interviewees representing regional and state authorities interpret interest contradictions concerning land use as most critical. Policy instruments on the state and EU level constantly change, but can also be acknowledged as a 'what if ... ?' question in an energy system model like the BeWhere model. On the contrary, issues like interest contradictions involve a multitude of actors and interests connected to ecosystems and ecosystem services, interests and rights of indigenous people, interests of business and enterprises, all interfering with the interest of producing biofuels based on forests. That is, several interests interfere in a geographical area, which results in a complex mess of interests, illustrating how the reality studied in the model can never be understood as a 'closed system' [40].

The potential users of the BeWhere model, as well as the developers of the model, are indeed aware of what a model can illustrate and what questions it might answer. However, in order to make the model realistic, it is constantly under development, including the addition of more parameters to be able to answer further questions. For example, one of the interviewed developers even mentions plans to include social aspects such as attitudes towards biofuel production in the BeWhere model in a Finnish case study. Even though this might be useful, and could be required by potential users, the increased number of parameters functioning as input to the model also results in increased uncertainty regarding the output. The complexity paradox, according to Oreskes [40], means that the more variables and parameters that are added to a model, the more uncertain it in fact becomes. Potential users, as well as developers, have proved in this study to be rather sceptical towards models, and the kinds of questions they can answer. Nevertheless, the interviews illustrate how interviewees believe in increased components and complexity as factors that might improve the model, while, according to Oreskes, it might as well be the other way around. Again, the closed systems that models represent can help answer certain 'what if ... ?' questions, but the more components there are, the more uncertain they become.

Finally, how can this study help us to understand how models can be used as 'tools' in decision-making? The BeWhere Sweden model, which has been the example in this paper, could obviously help to illustrate opportunities and obstacles regarding forest-derived biofuel production in Sweden, similar to how the BeWhere model in a smaller geographical context has previously been used to analyse the design of a charging infrastructure for electric buses [35]. However, on a broader level, the study also illustrates the complexity that characterises this policy area, where a multitude 
of different interests interact and where an energy system model can answer some of the "what if ... ?' questions, but never all of them. That is, the study shows how actors involved in investigations regarding forest-derived biofuel production are mostly concerned due to parameters that are not easily included in a parameterised energy system model.

Hence, the paper illustrates two important aspects: (1) researchers and experts involved with energy system modelling must reform the way they design, operate and present models and model outputs, and also engage in deeper interaction with actors from different sectors in order to more explicitly make society the subject of the work; and (2) the belief of expertise as a tool for consensus in decision-making must be questioned.

Future studies should therefore further investigate how energy system models are actually interpreted among their users, and how they are actually used for policy-making—not just how they are intended to be interpreted and used.

Acknowledgments: This project was carried out within the collaborative research program Renewable Transportation Fuels and Systems (Förnybara Drivmedel och System), Project No. 38118-1. The project has been financed by the Swedish Energy Agency and f3-the Swedish Knowledge Centre for Renewable Transportation Fuels. Economic support from Bio4Energy is also gratefully acknowledged. The authors would like to thank the interviewees, as well as the other project participants for input and comments. Four anonymous reviewers are gratefully acknowledged for the comments, which helped further improve this manuscript.

Author Contributions: The study was jointly planned by all three authors. Magdalena Fallde and Elisabeth Wetterlund planned the interviews. Magdalena Fallde conducted the interviews and analysed the data. The paper was written jointly by Magdalena Fallde and Elisabeth Wetterlund, with Johan Torén contributing comments and input for the literature review.

Conflicts of Interest: The authors declare no conflict of interest. The founding sponsors had no role in the design of the study; in the collection, analyses, or interpretation of data; in the writing of the manuscript, and in the decision to publish the results.

\section{References}

1. Regeringskansliet. En Sammanhållen Klimat-och Energipolitik-Klimat (A Cohesive Swedish Climate and Energy Policy_Climate); Governmental Bill: 2007/08:162; Regeringskansliet: Stockholm, Sweden, 2009. (In Swedish)

2. Government Offices of Sweden. Fossilfrihet på Väg (A Vehicle Fleet Independent of Fossil Fuels); Swedish Government Official Reports; SOU 2013:84; Government Offices of Sweden: Stockholm, Sweden, 2013. (In Swedish)

3. Government Offices of Sweden. En Klimat-och Luftvårdsstrategi för Sverige, Del 1 (A Climate and Air Pollution Treatment Strategy for Sweden_Part 1); Swedish Government Official Reports; SOU 2016:47; Government Offices of Sweden: Stockholm, Sweden, 2016. (In Swedish)

4. Swedish Transport Administration. Styrmedel och Åtgärder för att Minska Transportsystemets Utsläpp av Växthusgaser-Med Fokus på Transportinfrastrukturen (Policies and Measures to Decrease Greenhouse Gas Emissions from the Transport System); Swedish Transport Administration: Borlänge, Sweden, 2016. (In Swedish)

5. Swedish Energy Agency. Transportsektorns Energianvändning 2016 (Energy Use in the Transport Sector); Swedish Energy Agency: Eskilstuna, Sweden, 2017. (In Swedish)

6. Dahlgren, S.; Liljeblad, A.; Cerruto, J.; Nohlgren, I.; Starberg, K. Realiserbar Biogaspotential i Sverige år 2030 Genom Rötning och Förgasning (Practical Biogas Potential in Sweden by 2030 from Digestion and Gasification); WSP: Stockholm, Sweden, 2013. (In Swedish)

7. Phillips, R.B.; Jameel, H.; Chang, H.M. Integration of pulp and paper technology with bioethanol production. Biotechnol. Biofuels 2013, 6, 13. [CrossRef] [PubMed]

8. Pettersson, K.; Wetterlund, E.; Athanassiadis, D.; Lundmark, R.; Ehn, C.; Lundgren, J.; Berglin, N. Integration of next-generation biofuel production in the Swedish forest industry-A geographically explicit approach. Appl. Energy 2015, 154, 317-332. [CrossRef]

9. Mesfun, S.; Anderson, J.-O.; Umeki, K.; Toffolo, A. Integrated SNG Production in a Typical Nordic Sawmill. Energies 2016, 9, 333. [CrossRef]

10. Consonni, S.; Katofsky, R.E.; Larson, E.D. A gasification-based biorefinery for the pulp and paper industry. Chem. Eng. Res. Des. 2009, 87, 1293-1317. [CrossRef] 
11. Andersson, J.; Furusjö, E.; Wetterlund, E.; Lundgren, J.; Landälv, I. Co-gasification of black liquor and pyrolysis oil: Evaluation of blend ratios and methanol production capacities. Energy Convers. Manag. 2016, 110, 240-248. [CrossRef]

12. Ljungstedt, H.; Pettersson, K.; Harvey, S. Evaluation of opportunities for heat integration of biomass-based Fischer-Tropsch crude production at Scandinavian kraft pulp and paper mill sites. Energy 2013, 62, 349-361. [CrossRef]

13. Fornell, R.; Berntsson, T.; Åsblad, A. Techno-economic analysis of a kraft pulp-mill-based biorefinery producing both ethanol and dimethyl ether. Energy 2013, 50, 83-92. [CrossRef]

14. Haikonen, T.; Tuomaala, M.; Holmberg, H.; Ahtila, P. Energy efficiency in biorefineries-A case study of fischer-tropsch diesel production in connection with a pulp and paper mill. J-FOR 2011, 1, 71-75.

15. Nohlgren, I.; Lundqvist, P.; Liljeblad, A.; Hylander, N. Förutsättningar för Svensk Produktion av Fisher-Tropsch Diesel (A General Feasability Study on the Production of Fisher-Tropsch Motor-Fuels from Biomass in Sweden); Ångpanneföreningens Forskningsstiftelse: Stockholm, Sweden, 2010. (In Swedish)

16. Peck, P.; Grönkvist, S.; Hansson, J.; Lönnqvist, T.; Voytenko, Y. Systemic Constraints and Drivers for Production of Forest-Derived Transport Biofuels in Sweden-Part A: Report; Report No. 2016:09A; f3 The Swedish Knowledge Centre for Renewable Transportation Fuels: Göteborg, Sweden, 2016.

17. SFIF (Swedish Forest Industry Federation) Statistics. Available online: http://www.forestindustries.se/ forest-industry/statistics / (accessed on 1 August 2017).

18. Novotny, M.; Laestadius, S. Beyond papermaking: Technology and market shifts for wood-based biomass industries-Management implications for large-scale industries. Technol. Anal. Strateg. Manag. 2014, 26, 875-891. [CrossRef]

19. Hellsmark, H.; Söderholm, P. Innovation policies for advanced biorefinery development: Key considerations and lessons from Sweden. Biofuels Bioprod. Biorefin. 2017, 11, 28-40. [CrossRef]

20. Bennich, T.; Belyazid, S. The Route to Sustainability-Prospects and Challenges of the Bio-Based Economy. Sustainability 2017, 9, 887. [CrossRef]

21. Hellsmark, H.; Mossberg, J.; Söderholm, P.; Frishammar, J. Innovation system strengths and weaknesses in progressing sustainable technology: The case of Swedish biorefinery development. J. Clean. Prod. 2016, 131, 702-715. [CrossRef]

22. Näyhä, A.; Pesonen, H.-L. Strategic change in the forest industry towards the biorefining business. Technol. Forecast. Soc. Chang. 2014, 81, 259-271. [CrossRef]

23. Lidskog, R.; Sundqvist, G. The Role of Science in Environmental Regimes: The Case of LRTAP. Eur. J. Int. Relat. 2002, 8, 77-101. [CrossRef]

24. Wetterlund, E.; Pettersson, K.; Mossberg, J.; Torén, J.; Hoffstedt, C.; von Schenck, A.; Berglin, N.; Lundmark, R.; Lundgren, J.; Leduc, S.; et al. Optimal Localisation of Next Generation Biofuel Production in Sweden; Report No. 2013:8; f3 The Swedish Knowledge Centre for Renewable Transportation Fuels: Göteborg, Sweden, 2013.

25. Wetterlund, E.; Pettersson, K.; Lundmark, R.; Lundgren, J.; Athanassiadis, D.; Mossberg, J.; Torén, J.; von Schenck, A.; Berglin, N. Optimal Localisation of Next Generation Biofuel Production in Sweden-Part II; Report No. 2013:26; f3 The Swedish Knowledge Centre for Renewable Transportation Fuels: Göteborg, Sweden, 2013.

26. Leduc, S.; Natarajan, K.; Dotzauer, E.; McCallum, I.; Obersteiner, M. Optimizing biodiesel production in India. Appl. Energy 2009, 86, S125-S131. [CrossRef]

27. Leduc, S.; Lundgren, J.; Franklin, O.; Dotzauer, E. Location of a biomass based methanol production plant: A dynamic problem in northern Sweden. Appl. Energy 2010, 87, 68-75. [CrossRef]

28. Leduc, S.; Starfelt, F.; Dotzauer, E.; Kindermann, G.; McCallum, I.; Obersteiner, M.; Lundgren, J. Optimal location of lignocellulosic ethanol refineries with polygeneration in Sweden. Energy 2010, 35, 2709-2716. [CrossRef]

29. Schmidt, J.; Leduc, S.; Dotzauer, E.; Schmid, E. Cost-effective policy instruments for greenhouse gas emission reduction and fossil fuel substitution through bioenergy production in Austria. Energy Policy 2011, 39, 3261-3280. [CrossRef]

30. Wetterlund, E.; Leduc, S.; Dotzauer, E.; Kindermann, G. Optimal use of forest residues in Europe under different policies-Second generation biofuels versus combined heat and power. Biomass Convers. Biorefin. 2013, 3, 3-16. [CrossRef] 
31. Natarajan, K.; Leduc, S.; Pelkonen, P.; Tomppo, E.; Dotzauer, E. Optimal locations for second generation Fischer Tropsch biodiesel production in Finland. Renew. Energy 2014, 62, 319-330. [CrossRef]

32. Slegers, P.M.; Leduc, S.; Wijffels, R.H.; van Straten, G.; van Boxtel, A.J.B. Logistic analysis of algae cultivation. Bioresour. Technol. 2015, 179, 314-322. [CrossRef] [PubMed]

33. Campana, P.E.; Leduc, S.; Kim, M.; Olsson, A.; Zhang, J.; Liu, J.; Kraxner, F.; McCallum, I. Suitable and optimal locations for implementing photovoltaic water pumping systems for grassland irrigation in China. Appl. Energy 2017, 185, 1879-1889. [CrossRef]

34. Mesfun, S.; Sanchez, D.L.; Leduc, S.; Wetterlund, E.; Lundgren, J.; Biberacher, M.; Kraxner, F. Power-to-gas and power-to-liquid for managing renewable electricity intermittency in the Alpine Region. Renew. Energy 2017, 107, 361-372. [CrossRef]

35. Xylia, M.; Leduc, S.; Patrizio, P.; Kraxner, F.; Silveira, S. Locating charging infrastructure for electric buses in Stockholm. Transp. Res. Part C Emerg. Technol. 2017, 78, 183-200. [CrossRef]

36. Leduc, S.; Wetterlund, E.; Dotzauer, E.; Schmidt, J.; Natarajan, K.; Khatiwada, D. Policies and Modeling of Energy Systems for Reaching European Bioenergy Targets. In Handbook of Clean Energy Systems; Yan, J., Ed.; John Wiley \& Sons, Ltd.: Chichester, UK, 2015; pp. 1-17.

37. Annevelink, E.; Elbersen, B.; Leduc, L.; Staritsky, I. D3.5 Formalized Stepwise Approach for Implementing Logistical Concepts Using BeWhere and LocaGIStics. Available online: http://edepot.wur.nl/405764 (accessed on 3 October 2017).

38. Fischer, F. Democracy and Expertise: Reorienting Policy Inquiry; Oxford University Press: Oxford, UK, 2009; ISBN 9780199565245.

39. Jasanoff, S. States of Knowledge: The Co-Production of Science and Social Order; Jasanoff, S., Ed.; Routledge: London, UK, 2004; ISBN 0415403294.

40. Oreskes, N. The role of quantitative models in science. In Models in Ecosystem Science; Canham, C.D., Cole, J.J., Lauenroth, W.K., Eds.; Princeton University Press: Princeton, NJ, USA, 2003; pp. 13-31.

41. Oreskes, N. Evaluation (not validation) of quantitative models. Environ. Health Perspect. 1998, 106, 1453-1460. [CrossRef] [PubMed]

42. Horschig, T.; Thrän, D. Are decisions well supported for the energy transition? A review on modeling approaches for renewable energy policy evaluation. Energy. Sustain. Soc. 2017, 7, 5. [CrossRef]

43. Nakata, T.; Silva, D.; Rodionov, M. Application of energy system models for designing a low-carbon society. Prog. Energy Combust. Sci. 2011, 37, 462-502. [CrossRef]

44. Bhattacharyya, S.C.; Timilsina, G.R. A review of energy system models. Int. J. Energy Sect. Manag. 2010, 4, 494-518. [CrossRef]

45. Jebaraj, S.; Iniyan, S. A review of energy models. Renew. Sustain. Energy Rev. 2006, 10, 281-311. [CrossRef]

46. Van Beeck, N. Classification of Energy Models; FEW Research Memorandum; Tilburg University, Operations Research: Tilburg, The Netherlands, 1999; Volume 777.

47. Grundmann, R. The role of expertise in governance processes. For. Policy Econ. 2009, 11, 398-403. [CrossRef]

48. Haas, P. When does power listen to truth? A constructivist approach to the policy process. J. Eur. Public Policy 2004, 11, 569-592. [CrossRef]

49. Kvale, S.; Brinkmann, S.; Torhell, S.-E. Den Kvalitativa Forskningsintervjun; Studentlitteratur: Lund, Sweden, 2009; ISBN 9789144055985.

50. Lundgren, J.; Waldheim, L.; Marklund, M.; Landälv, I.; Gebart, R. Strategisk Innovationsagenda Biomasseförgasning och Pyrolys-Nycklar till Fossilfrihet (Strategic Innovation Agenda Biomass Gasification and Pyrolysis); Vinnova, the Swedish Energy Agency and FORMAS: Stockholm, Sweden, 2016. (In Swedish)

51. Toppinen, A.; Pätäri, S.; Tuppura, A.; Jantunen, A. The European pulp and paper industry in transition to a bio-economy: A Delphi study. Futures 2017, 88, 1-14. [CrossRef]

52. Confederation of European Paper Industries (CEPI). European Pulp E Paper Industry. Key Statistics 2016; Confederation of European Paper Industries (CEPI): Brussels, Belgium, 2017.

53. Vakkilainen, E.K.; Välimäki, E. Effect of Lignin Separation to Black Liquor and Recovery Boiler Operation. In Proceedings of the TAPPI's 2009 Engineering, Pulping, and Environmental Conference, Memphis, TN, USA, 11-14 October 2009. 
54. Jönsson, J.; Pettersson, K.; Harvey, S.; Berntsson, T. Comparison of options for debottlenecking the recovery boiler at kraft pulp mills-Economic performance and $\mathrm{CO}_{2}$ emissions. In Proceedings of the 25th International Conference on Efficiency, Cost, Optimization and Simulation of Energy Conversion Systems and Processes, ECOS 2012, Perugia, Italy, 26-29 June 2012; pp. 270-286.

55. Mesfun, S.; Lundgren, J.; Grip, C.-E.; Toffolo, A.; Nilsson, R.L.K.; Rova, U. Black liquor fractionation for biofuels production-A techno-economic assessment. Bioresour. Technol. 2014, 166, 508-517. [CrossRef] [PubMed]

56. Directorate-General for Mobility and Transport. Building up the Future-Sub Group on Advanced Biofuels (SGAB): Final Report; Maniatis, K., Landälv, I., Waldheim, L., van den Heuvel, E., Kalligeros, S., Eds.; Directorate-General for Mobility and Transport: Brussels, Belgium, 2017.

57. Kastensson, Å.; Börjesson, P. Hinder för Ökad Användning av Höginblandade Biodrivmedel $i$ den Svenska Fordonsflottan; Report No. 2017:02; f3 The Swedish Knowledge Centre for Renewable Transportation Fuels: Göteborg, Sweden, 2017.

58. Lindahl, K.B.; Johansson, J.; Lidskog, R.; Ranius, T.; Roberge, J.-M. The Swedish forestry model: More of everything? For. Policy Econ. 2017, 77, 44-55. [CrossRef]

59. Regeringskansliet. En Skogspolitik $i$ Takt Med Tiden (A Forest Policy in Line with the Times); Governmental Bill 2007/08:108; Regeringskansliet: Stockholm, Sweden, 2008. (In Swedish)

60. Governmental Commission. Möjligheter till Intensivodling av Skog (MINT). Slutrapport. (Possibilities for Intensive Forestry. Final Report); SLU: Uppsala, Sweden, 2009. (In Swedish)

61. Regeringskansliet. En Svensk Strategi för Biologisk Mångfald och Ekosystemtjänster (A Swedish Strategy for Biodiversity and Ecosystem Services); Governmental Bill 2013/14:141; Regeringskansliet: Stockholm, Sweden, 2014. (In Swedish)

62. County Administrative Board of Norrbotten Världsarvet Laponia (Laponia World Heritage, in Swedish). Available online: http://www.lansstyrelsen.se/Norrbotten/Sv/djur-och-natur/skyddadnatur/varldsarvet-laponia/Pages/default.aspx (accessed on 22 June 2017).

(C) 2017 by the authors. Licensee MDPI, Basel, Switzerland. This article is an open access article distributed under the terms and conditions of the Creative Commons Attribution (CC BY) license (http:/ / creativecommons.org/licenses/by/4.0/). 